\title{
Hyperreality in a Football Live on Television
}

\author{
Rojil Nugroho Bayu Aji \\ History Education Department \\ Universitas Negeri Surabaya \\ Surabaya, Indonesia \\ rojilaji@unesa.ac.id
}

\author{
Eko Satriya Hermawan \\ History Education Department \\ Universitas Negeri Surabaya \\ Surabaya, Indonesia \\ ekohermawan@unesa.ac.id
}

\author{
Riyadi \\ History Education Department \\ Universitas Negeri Surabaya \\ Surabaya, Indonesia \\ riyadi@unesa.ac.id
}

\begin{abstract}
Today spotlight of direct camera in a football match is inevitable. Hundreds of cameras are always prepared in every football match in order to catch every second of the events, both inside and outside the stadium. As the result, we can access football matches anywhere from our television or our cellphone. This article was aimed to show how football matches live on television and cellphone is not neutral. There were many values appeared because it was not meant to be real and exactly the same as the football matches we watch with our own eyes. This was a hyperreality in football matches live on television that we enjoy seeing it over the years.
\end{abstract}

Keywords-hyperreality, football, live macth, television

\section{INTRODUCTION}

Johan Huizinga says that humans are "Homo Ludens", playful creatures. "Homo Ludens" is a concept that emerges and is discovered through cultural processes. Man, as a creature of play is a cultural phenomenon. It is found in a simple form through everyday life. To maintain the balance of life, human is not a subject who has to work and do activity continuously all the time. Sometimes, human apparently needs other activities to relax and play. Exercise is a real part of a game. Therefore, ultimately sport is not solely related to the achievement of the sport.

Sport is a significant part of the modern world. While the world is changed and developed into a modern world, its institutional structures and cultural traditions will get a huge impact, says, the sport developed and evolved. Sport is an integral part of modernity and modernity is an integral part of sport [1]. Football is the most popular sport game in the world. By the early $20^{\text {th }}$ century, football had spread across the world. Despite some fractious international relationships, football continued to rise in popularity [2].

There are no place that can give much contributions to develop one's feeling or emotion. The memories of a stadium elide into more comprehensive reflections on a multiplicity of emotions. Even in the midst of a cheering crowd, the stadium will always be a place for quiet contemplation for everyone [3]. Football was also a competitive sport that was contested. It started with the qualification in each regional federation. It became a prestigious and favorite sport that competed in sport international championship. Nowadays, football and television cannot be separated each other. Television is a tool to form of mass consumption including in football live show. This is an important thing to interpret that there is a new framing through football game, especially football live show on television.

There are two important things to understand about football and television. First, most professional football players are indeed consumed through television rather than "in situ". Fans who come to the stadium will hardly to know the football player. It is easily to recognize the football player by following the television shows. Second, those fans who watch football matches on television engage a practice which in line with the cultural and social framing of television consumption. That is why, football then fulfills desires of audiences classically associated with other forms of visual entertainment. It is called as home-centered [4].

The meeting point between football match and television is predicted to reduce the interest of spectators to come and watch a live match in the stadium. However, in the late 1970s, when the appearance of football impressions on television began regularly and helped the appeal of football to the public, especially in Europe [5]. It is slowly affecting how society, especially for the football audiences in their homes through television live show.

\section{METHOD}

This article used historical methods namely heuristic (collecting sources), critical of sources, interpretation and historiography. This article also used some literature studies and books about football, globalization and how football is 
currently entering the world of television. Furthermore, the writer of this article also used some news about match reports and match comments taken from online news on the internet.

\section{RESULTS AND DISCUSSION}

If pornography is considered more sensual than sex, can football impressions at this time be considered sportier than the real football? Through increasingly sophisticated media broadcasting, a football game showed that geographical boundaries could not eliminate an emotion and tension to enjoy the football matches. As a television show, a football match came as a piece only because we could not see all the things happened in the stadium. Football is played by 22 people at once, but as a spectator at home, we could not watch them all at the same time[6].

Zen explained that today football pieces of information and communication technology advances were like a simulation, a process in which images (representations) or objects replace its position through the approach of Baudrillard theory. Through the sophistication of audio-visual technology, the atmosphere of football matches in the stadium as if presented in the home through a football live show on television. This is the case that makes football impressions eventually replace football "per sei" played on the pitch.

Do not be surprised if the fans who watch in the cafe, for example, could also react the same as the supporters in the stadium. Commonly they sang, carried banners and even light a smoky flare (no matter where they were, in the cafe or in other places). In fact, when supporters of a team visit the cafes owned by one of supporters of their opponents, they also expressed and felt the same tension as when they visit the real stadium. They were so serious and full of appreciations. This was the situation where football live shows on the screen could be as intriguing as, and even replaced, the actual football that was played in the stadium.

The BBC premiered football launched for the first time on television in 1937. The aired match was between Arsenal versus Arsenal that reserved at Highbury Stadium, London. The trials could only be seen in houses close to the stadium. The following year, the BBC aired an FA Cup final match live for the first time between Huddersfield Town versus Preston North End. In addition, in the same year, the first international match aired the match between UK versus Scotland. Then, the 1954 world cup was first broadcast live. The development of live broadcast football on television was growing. As reported by The Guardian, the sale and purchase of broadcasting rights football game occurred in 1988. At that time, media tycoon Rupert Murdoch bid up to 47 million pounds for exclusive football broadcasting rights. Earlier since the 1960s, football broadcasted in the UK broadcasted ITV and BBC in the UK[7].

It was widely acknowledged that television had transformed, and was constantly transforming, professional football in the way in which it was organized, played and spectated. New deals were continually struck for astronomical fees as television companies, multinational sponsors and governing bodies who seek to exploit the world game commercially. In Britain, the relationship between football and television had not, however, always been sanguine and throughout their historical association the struggles over the representation of the sport through the lens of the camera and the microphone, who this mediation was for, and when or how it was delivered, and had often proved volatile [8].

There was a lot of controversy on the football field and then got a negative response in the 2014 World Cup in Brazil. The controversy was a Japanese referee Yichi Nishimura's decision to give Brazil a penalty when he met Croatia in the opening match of the World Cup. In the French game against Honduras, there was the term "ghost goal" because of the application of the line technology in the field named Goal Line Technology (GLT). It resulted two assessments when Karim Benzema did shooting in the game, that was "no goal" and "goal" when the ball was on the goalpost and crossed the line.

Furthermore, Luis Suarez was caught on camera biting the arm of Italian defender Giorgio Chiellini. The bite incident also became the headline of sports around the world because it had been three times Suarez doing it, biting soccer players. Fortunately, this time referee Marco Rodriguez from Mexico who led the match did not give any punishment related to the incident. There were pros and cons between those who criticized and who supported Luis Suarez. Chiellini argued that Suarez should get a red card and the match between Italy and Uruguay can be different. After the incident, Diego Godin scored a goal that eventually led to Uruguay's 1-0 victory over Italy.

Meanwhile, Uruguay team captain Diego Lugano defensively outlast Luis Suarez. "What incidents? I do not know what the incident is talking about? Do you have any problems with Suarez? Pieces of photographs did not show anything. They (journalists) just connected it with the photo. Everyone knew that the English media had a problem with Suarez. They had to sell their own news and sensational news, "Lugano told the BBC.

During the 2010 World Cup in South Africa, there was controversy as the referee led the World Cup game and gained the attention of the mass media. This concern has led to Deutscher Fussball Bund (DFB) Referee Commission Chair, Herbert Fandel concerned that the dramatization and exploitation of the spotlight. The former referee asked the television station not to dramatize the replay and slow motion scene in several incidents while broadcasting the Bundesliga during the 2010-2011 season. Fandel preferred that slow motion scene in football should be abolished because it meant the referee would be suffered under great pressure. One referee's fault could be the newspaper headline for weeks.

Many people and football commentators gave reactions to reject the idea that was initiated by Fandel. They argued that the referee's decision was just like a goalkeeper's rescue and the creation of a goal was part of the soccer culture and that will be an exciting discussion anytime. In a reader poll on spiegel.de, the football fans were also still wanted to watch the replay and slow motion scene in a live football broadcasting.

According to Jean Baudrillard, people in the modern era lived in a simulacrum world full of simulations. Everything that passes through man was nothing real. Everything has been 
replaced by the simulated codes, spectacle and hyperrealism. Information and technology advances had a major influence in constructing reality, especially in the form of impressions or broadcast through the media, both television and print media, whether directly or indirectly. Media in society today had an important role in the dissemination of reality. After that, the society accepted and absorbed the informations as a truth. But all the information that was disseminated could be just a false reality. Many of the dramatizations that appeared in the impressions through the media were generally controlled by the production house that made it no longer controlled the main actors who had the story.

Many fans voiced their impression that the stadium experience often differed significantly from what they saw in television highlights. Jean Baudrillard invited us to remember and understand about "the dissolution of television into life, the dissolution of life into television". Television football had rationalized the consumption of matches by prioritizing vision over other forms of perception such as sound (which television, of course, dramatically reconstructs) and the absent dimensions of smell, feel and touch [4].

Take a glance of 2012 European Cup semi-final match between Italy against Germany that won by Italy with a score of 2-1. There were scenes of German women shed tears after Mario Balotelli scored against Manuel Neuer, a goal keeper of Germany. Through live television at the time, the German women's replay scene that shed tears after Mario Balotelli's action celebrated his goal by taking off his costume.

The atmosphere in the television show looked so dramatic because the woman looked so sad with Balotelli's goal and regretted Italy's 2-0 lead. If we looked further, it did not reflect the facts that actually happened during the game. Many soccer audiences and soccer commentators were skeptical about the show that looked almost perfect. Uefa who was in charge of the live broadcast process was accused of manipulation by combining two different moments of time arranged as chronologically. One of the German television stations, ARD said that the crying woman scene was taken before kickoff begins.

After that, the woman named Andrea Dusseldorf knew that she was crying when Balotelli scored after getting notified via email from his friend. Andrea said that she was touched and cried for singing the German national anthem at that time before the game began, it was like reinventing her country through football and not because Germany suffered of the defeat. "My tears are not because I am sad, but because touched to see the German players sing the national anthem. I am only touched and too emotional with the German anthem, "he explained it in Sueddeutsche Zeitung newspaper.

The head of ARD Germany Television Editor Joerg Schoenenborn also highlighted the live show of matches between Germany against Holland at the 2012 European Cup. In the game, there was a replay of Joachim Loew who was teasing a ball boy. In the show, it was seen that Joachim Loew picked up the ball held by the ball boy in the match against the
Netherlands. However, the actual event was Joachim loew just made a joke when the game did not start yet.

Similarly, in Indonesia, football also became one of the impressions to attract viewers. This country first had a television station when Television Republik Indonesia (TVRI) began airing on August 24, 1962. TVRI then covered the Asian Games held in Jakarta. One of the sports covered was football. In the future, TVRI was active to cover various multi-branch sports events. Also broadcast football matches, including the World Cup when private television did not exist yet. One of the most remembered programs was "From Arena to Arena" which was hosted by Max Sopacua containing sports information including football. Furthermore, football game footage became a favorite event, when football fans had no chance to watch the live events. Several years later, there are some television programs appeared that specifically discussed about football in private television stations. Although the first broadcast football on TVRI, the football live shows on Rajawali Citra Televisi Indonesia RCTI) which began to air in 1989 satisfy the public more by presenting a world-class football match. The Italian league that soared in the 1990s every weekend was broadcast to Indonesian family rooms. In the end, private televisions such as SCTV, ANTV and television subscription were presented on Indonesian television along with the global television network [9].

Football shows on television can become hyperbole when commentators give their comments in the game. Live football commentators are needed to guide viewers through their predictions (with impartiality), provide additional references to the public, answer the audience's curiosity, and entertain. However, there were some strange things spoken by football commentators in Indonesia.

For example, Valentino Simanjuntak as a game commentator when the Indonesian national team U-19 competed and broadcasted by a certain television. Apparently, he did not stop making the audience wonders. For those who watched the game on television, it might feel strange and surprised to hear comments throughout the game. Valentino had a lot of strange and odd-sounding vocabulary that he uttered in his commentary.

In contrast to other commentators who seem formal and intelligent analyze the match. Valentino often says the words "Jebret, LDR (long distance relationship) kick, Scooped, Crossing Splitting the Seas, ball crossing breaking down the household" were some of the strange words he expressed throughout the game as commentators. Netizens wondered and wondered how Valentino could make those words in a football match. 
田

MissLya_

@NRahmadhani_03

Tendangan LDR Itu Gimana Ceritanya?? *MikirKeras \#GarudaNusantaraJuara

7:23 PM - Sep 7, 2017 - Panakkukang, Indonesia

๑】 $\bigcirc$

(

6. MasTON

Kasihan rumah tangga philipina \#GarudaNusantaraJuara

7:23 PM - Sep 7, 2017

Fig. 1. Reaction of netizens in social media about Valentino's opinion as a football commentator. They tried to understand and asked about what it means.

When we think critically about football live performances and commentators. Thus, it is worth to point out that what the commentator said was unrelated to football as a match.

\section{CONCLUSION}

Football matches broadcast live on television is not an actual football match. There are various values that affect a football live show on television. A cameraman and a live television editor are not a value-free person when taking snapshots through a camera. Unlike watching the match inside a stadium, soccer audiences and fans who watch football live on television have no freedom while doing it. What they watch are chosen and interpreted by the cameraman, editor and television ideology.

On television, we cannot distinguish between what is the actual event in the match and which is the only artificial or television construction, which facts and what is fiction, what is genuine and which are simulated. All of us, according to Baudrillard, live in this simulacrum world, enjoy football matches live on television without trying to think critically of it.

\section{REFERENCES}

[1] P. C. and P. Beedie, Sport Sociology. UK: Learning Matters, 2008.

[2] Franklin Foer, Memahami Sunia Lewat Sepak Bola, Kajian Tak Lazim Tentang Sosial-Politik Globalisasi. Tangerang: Marjin Kiri, 2014.

[3] A. Bairner, "Emotional grounds: Stories of football, memories, and emotions,” Emot. Sp. Soc., vol. 12, pp. 18-23, 2014.

[4] Cornel Sandvoss., A Game of Two Halves, Football, Television and Globalisation. USA and Canada: Routledge, 2003.

[5] R. Giulianotti, Football, A Sociology of the Global Game. UK: Blackwell Publisher, 1999.

[6] R. S. Zen, Simulakra Sepak Bola. Yogyakarta: Indie Book Corner, 2016.

[7] D. D. Kardi, "History of Television Today and Football Match,” 2016. .

[8] H. Richard, "A pageant of sound and vision: football's relationship with television, 1936-60," Int. J. Hist. Sport, vol. 15, no. 1.

[9] S. Hasbi, "Football in Media," 2014. .

[10] 